Article

\title{
Belowground Carbohydrate Reserves of Mature Southern Pines Reflect Seedling Strategy to Evolutionary History of Disturbance
}

\author{
Joshua T. Mims ${ }^{1}$, Joseph J. O'Brien ${ }^{2}$ and Doug P. Aubrey ${ }^{3,4, *}$ \\ 1 Department of Biology, Georgia Southern University, Statesboro, GA 30460, USA; jm05493@gmail.com \\ 2 USDA Forest Service, Southern Research Station, Athens, GA 30602, USA; jjobrien.cfds@gmail.com \\ 3 Savannah River Ecology Laboratory, University of Georgia, Aiken, SC 29802, USA \\ 4 Daniel B. Warnell School of Forestry and Natural Resources, University of Georgia, Athens, GA 30602, USA \\ * Correspondence: daubrey@uga.edu; Tel.: +1-803-725-0135
}

Received: 5 September 2018; Accepted: 16 October 2018; Published: 19 October 2018

\begin{abstract}
Carbohydrate reserves provide advantages for mature trees experiencing frequent disturbances; however, it is unclear if selective pressures operate on this characteristic at the seedling or mature life history stage. We hypothesized that natural selection has favored carbohydrate reserves in species that have an evolutionary history of frequent disturbance and tested this using three southern pine species that have evolved across a continuum of fire frequencies. Longleaf pine (Pinus palustris) roots exhibited higher maximum starch concentrations than slash (P. elliottii) and loblolly (P. taeda), which were similar. Longleaf also relied on starch reserves in roots more than slash or loblolly, depleting 64,41 , and $23 \mathrm{mg} \mathrm{g}^{-1}$ of starch, respectively, between seasonal maximum and minimum, which represented $52 \%, 45 \%$, and $26 \%$ of reserves, respectively. Starch reserves in stems did not differ among species or exhibit temporal dynamics. Our results suggest that an evolutionary history of disturbance partly explains patterns of carbohydrate reserves observed in southern pines. However, similarities between slash and loblolly indicate that carbohydrate reserves do not strictly follow the continuum of disturbance frequencies among southern pine, but rather reflect the different seedling strategies exhibited by longleaf compared to those shared by slash and loblolly. We propose that the increased carbohydrate reserves in mature longleaf may simply be a relic of selective pressures imposed at the juvenile stage that are maintained through development, thus allowing mature trees to be more resilient and to recover from chronic disturbances such as frequent fire.
\end{abstract}

Keywords: fire; non-structural carbohydrates; roots; starch; stored carbon

\section{Introduction}

The allocation of assimilated carbon towards storage at the expense of measurable aboveground growth and reproduction is a trait that should be subject to selective pressures because it can influence fitness. A possible advantage of carbon storage could be the ability to repair damaged tissue after disturbance events such as fire, insect outbreaks, and drought since loss of photosynthetic tissue can affect carbon assimilation, although to different degrees depending on frequency and intensity. Post-disturbance recovery from catastrophic disturbances often depends on the recruitment of new individuals from seed; however, post-disturbance recovery from low intensity chronic disturbances usually depends on the repair and regeneration of damaged tissues in mature trees. Thus, there is potential selective pressure favoring carbohydrate storage, especially in species experiencing chronic disturbances. Chronic disturbances, such as frequent surface fire, can scorch foliage of mature trees and decrease the production of photosynthate to levels below what is required to meet respiratory 
demands [1]. Under these circumstances, non-structural carbohydrates (NSCs) are mobilized to compensate for the insufficient supply of current photosynthate required to maintain the metabolism of existing cells as well as to refoliate the canopy, thereby decreasing the stored carbohydrate pool. This strategy of storing carbohydrates may provide an advantage for mature individuals experiencing frequent disturbances [1-3]. Alternatively, the advantage conferred by increased stored carbohydrate reserves under chronic disturbance could be a trait favored by selection at a critical life history stage that maintains benefits at later stages-a concept analogous to developmental inertia as described by Minelli [4,5]. Under this scenario, differences in seedling life history strategy that require different reservoirs of stored carbohydrates to successfully recruit to maturity may be more resilient to disturbance as mature trees because large stored carbohydrate reserves are maintained through development.

Longleaf pine (Pinus palustris Mill.), slash pine (Pinus elliottii Engelm.), and loblolly pine (Pinus taeda L.) are widely distributed tree species of the southeastern US. While mature trees of all three species are clearly adapted to low-intensity surface fires [6,7], they have been placed on a continuum with respect to purported exposure to varying fire frequency over evolutionary time. Among these species, longleaf pine experience fire with the highest frequency. Fires can occur annually in longleaf pine ecosystems [8]. Slash pine are purported to experience fire at an intermediate frequency [9]. At the other end of the continuum is loblolly pine, considered the least fire-resistant of these three southern pine species [10]. These arguments, however, remain suspect and do not relate directly to fire tolerance of mature trees as all three species can burn as often as every three years as evidenced by fire management of loblolly in places such as Piedmont National Wildlife Refuge and slash pine in Apalachicola National Forest among others. Boring bark beetles are a biotic disturbance that may have also played a role in the evolutionary history of Pinus species [11-13]. These three southern pine species differ in their resistance to boring insects and can be placed along a continuum like that of fire frequency with respect to their relative resistance. Longleaf and slash pines have oleoresin that has moderate to high viscosity, flow, and yield along with a mixture of monoterpenes and resin acids that make them more resistant to bark beetle attack than loblolly $[14,15]$. Loblolly is the least resistant to bark beetle attack and loblolly stands have been shown to experience a greater number of infestations than longleaf [14]. Subtle differences in the evolutionary history of these closely related species may result in differences in stored carbohydrate pools.

There does, however, exist a major developmental difference among the species; they can be classed into two distinct seedling strategies that result in fire-tolerant (longleaf) versus fire-sensitive (slash and loblolly) seedlings. Briefly, longleaf seedlings persist in a "grass stage" for up to a decade following germination [16]. The dense needles envelope and protect the apical bud from fire during the grass stage and most of the assimilated carbon is allocated belowground to develop a large root system that acts, at least in part, as a reservoir for stored carbohydrates [17]. This large reservoir of stored carbohydrates provides the construction capital for seedlings to bolt from the grass stage to a sapling stage that places the apical bud above the height where frequent, low-intensity fires could cause damage [18]. Slash and loblolly seedlings, however, lack the protective features conferred by a grass stage and thereby remain fire-sensitive for a number of years following germination (see [19] for images contrasting seedling morphology of these species). Rather than preferentially allocate assimilated carbon toward a belowground carbohydrate reservoir, slash and loblolly seedlings allocate carbon towards rapid aboveground growth. Whereas both of these strategies have proved successful for seedlings to reach the canopy, become fire-tolerant mature trees, and reproduce, the strategy of longleaf requires large amounts of stored carbohydrates, whereas the strategy shared by slash and loblolly does not. Moreover, stored carbohydrates allow longleaf to persist as seedlings in the understory for many years and through multiple fires. Indeed, in alignment with their regeneration strategies, seedlings of longleaf pine exhibited higher carbohydrate storage reserves in taproots compared to loblolly and slash pine [19]. It is plausible that selective pressures favoring large carbohydrate storage reservoirs have exerted a strong influence on longleaf at the seedling stage, but have persisted through 
development, thus allowing mature trees to be more resilient and to recover from chronic disturbances such as frequent fire.

Our aim was to determine if selective pressures have influenced patterns of carbohydrate storage of these three southern pine species. We hypothesized that disturbance history (i.e., fire frequency or beetle infestations) has influenced carbohydrate reserves at the mature life history stage, such that species will exhibit patterns of carbohydrate storage that mirror the purported evolutionary history of disturbance frequency. Alternatively, the advantage conferred by increased carbohydrate reserves under chronic disturbance could be a trait favored by selection at the seedling life history stage that maintains benefits at later stages-a concept analogous to developmental inertia. Here, we report on the relationship of carbohydrate reserves, disturbance history, and seedling strategy across these co-occurring pine species. Briefly, we sampled seasonal minimum and maximum stored carbohydrate concentrations in stems and coarse roots of these three southern pine species grown on the same site. If selective pressures have operated on carbohydrate reserves at the mature life history stage, then we expect reserves to be highest in longleaf, intermediate in slash, and lowest in loblolly. If selective pressures have operated on carbohydrate reserves at the seedling stage and differences in storage were maintained through maturity, then we expect carbohydrate reserves to be larger in longleaf and similar in slash and loblolly. However, if selective pressures have operated on carbohydrate storage at the seedling stage and differences in storage were not maintained through maturity, then we expect no differences in carbohydrate storage reserves among these three species.

\section{Materials and Methods}

\subsection{Study Site Description}

The study was conducted on a 5.26 ha mixed pine forest on privately owned land in Hazlehurst, Georgia, USA $\left(31^{\circ} 41^{\prime} \mathrm{N}, 82^{\circ} 34^{\prime} \mathrm{W}\right)$ at approximately $59 \mathrm{~m}$ above sea level. This area receives a 10 -year mean \pm standard deviation (SD) annual precipitation of $1210.7 \pm \mathrm{mm}$ with a mean annual high temperature of $31.1 \pm 0.6^{\circ} \mathrm{C}$ and a mean annual low temperature of $16.8 \pm 1.2{ }^{\circ} \mathrm{C}$. The study site consists of planted loblolly and slash pine trees with naturally regenerated longleaf pine and various oak species scattered throughout. The study site is comprised of $57.7 \%$ Kershaw sand and $42.3 \%$ Troup sand ("Web Soil Survey," 2015).

\subsection{Experimental Design}

Twelve trees from each species between 20 to $25 \mathrm{~cm}$ dbh were randomly selected and inspected to ensure there were no diseases or obvious visible injuries that could have potentially affected the amount of carbon stored. Stem cores and coarse root samples were collected from the same individual trees in October and the following March, periods that reflect the seasonal minimum and maximum, respectively, for starch [3] which is the NSC component believed to play the largest role in storage [20]. We focused our belowground efforts on coarse roots because they represent the largest belowground storage reservoir - both in terms of overall mass and starch concentration-and they exhibit more dynamic seasonal patterns of accretion and depletion relative to the finest roots [3]. Stem core samples were taken from each tree at breast height using an increment borer. The stem cores represented the section from the center of the tree to the phloem. Coarse roots were traced from the base of each tree and a representative section was removed with clippers. All coarse root sections were approximately $1.5 \mathrm{~cm}$ in diameter. Tissue samples were sealed in plastic bags and placed on ice in a cooler to slow enzymatic activity before being transported to the laboratory. Samples were placed in an oven at $60^{\circ} \mathrm{C}$ to a constant mass. Dried samples were ground to a fine powder using an 8000D Mixer/Mill ball grinder (SPEX Sample Prep, Metuchen, NJ, USA) and transferred into plastic scintillation vials. Starch (insoluble), sugar (soluble), and total NSC (starch + sugar; hereafter referred to as TNC) concentrations were assessed for each root category using a phenol-sulfuric acid method [21] described previously by Aubrey et al. [1]. 


\subsection{Statistical Analysis}

We compared NSC concentrations and content as a function of species, organ, and month with repeated measures ANOVA using the mixed model procedure (PROC MIXED) of SAS (Version 9.4, SAS Inc., Cary, NC, USA) with a type-I error rate of 0.05 . To model the correlation within experimental units over time, we analyzed each response using common covariance structures appropriate for data collected at equal temporal spacing within and among experimental units and used $\mathrm{AIC}_{C}$ to determine which structure best fit each model. Our experimental unit was the individual tree $(n=12)$. Time $(n=2)$ was treated as a repeated factor, while species $(n=3)$ and organ $(n=2)$ were treated as fixed factors. Treatment means were compared using Tukey's Honestly Significant Difference (HSD) test. Significant interactions were decomposed using tests of simple main effects. Prior to analysis of variance (ANOVA), we assessed normality of sugar, starch, and TNC data using the Shapiro-Wilks goodness-of-fit-tests as well as normality and box plots in the univariate procedure of SAS (PROC UNIVARIATE).

\section{Results}

Sugar, starch, and TNC concentrations differed among species, between organs, and across time, but these main effects were not independent of each other (i.e., 2- and 3-way intercations were observed) and these interactions were not consistent across NSC components. Mean \pm standard error (SE) sugar, starch, and TNC for each species-by-organ-by-time combination can be found in Table 1. Statistical results and figures illustrating data pooled across appropriate levels corresponding to interactions are provided in the sections below for each NSC component.

Table 1. Mean ( \pm SE) sugar, starch, and TNC for each species-by-organ-by-time combintaion.

\begin{tabular}{|c|c|c|c|c|c|c|c|}
\hline \multirow[b]{2}{*}{ Species } & \multirow[b]{2}{*}{ Month } & \multicolumn{3}{|c|}{ Stem } & \multicolumn{3}{|c|}{ Root } \\
\hline & & $\begin{array}{c}\text { Sugar } \\
\left(\mathrm{mg} \mathrm{g}^{-1}\right)\end{array}$ & $\begin{array}{c}\text { Starch } \\
\left(\mathrm{mg} \mathrm{g}^{-1}\right)\end{array}$ & $\begin{array}{c}\text { TNC } \\
\left(\mathrm{mg} \mathrm{g}^{-1}\right)\end{array}$ & $\begin{array}{c}\text { Sugar } \\
\left(\mathrm{mg} \mathrm{g}^{-1}\right)\end{array}$ & $\begin{array}{c}\text { Starch } \\
\left(\mathrm{mg} \mathrm{g}^{-1}\right)\end{array}$ & $\begin{array}{c}\mathrm{TNC} \\
\left(\mathrm{mg} \mathrm{g}^{-1}\right)\end{array}$ \\
\hline \multirow{2}{*}{ Pinus taeda } & October & $7.4(0.4)$ & $73.8(4.3)$ & $81.2(4.4)$ & $41.3(1.8)$ & $66.3(2.1)$ & $107.7(2.8)$ \\
\hline & March & $8.0(0.5)$ & $69.7(2.5)$ & $77.7(2.8)$ & $36.7(2.1)$ & $89.5(5.1)$ & $126.1(5.3)$ \\
\hline \multirow[b]{2}{*}{ Pinus elliottii } & October & $5.7(0.5)$ & $72.9(4.0)$ & $78.7(4.4)$ & $39.0(3.3)$ & $50.4(3.3)$ & $89.5(4.1)$ \\
\hline & March & $6.7(0.3)$ & $69.7(3.2)$ & $76.4(3.5)$ & $34.3(2.8)$ & $91.0(7.1)$ & $125.4(7.5)$ \\
\hline \multirow{2}{*}{ Pinus palustris } & October & $6.1(0.5)$ & $62.2(4.7)$ & $68.4(4.6)$ & $63.7(5.8)$ & $58.6(6.6)$ & $122.3(10.8)$ \\
\hline & March & $8.0(0.3)$ & $63.7(3.7)$ & $71.7(3.7)$ & $51.9(5.8)$ & $123.5(8.4)$ & $175.3(12.2)$ \\
\hline
\end{tabular}

\subsection{Sugar Concentrations}

Sugar concentrations differed among species, between organs, and changed through time; however, these individual effects were not always independent. Longleaf roots exhibited higher sugar concentrations than loblolly and slash, which exhibited similar concentrations (Figure 1); however, concentrations of stems were similar among all species (species $\times$ organ interaction; $p<0.0001$ ). Roots exhibited sugar concentrations $\left(44.5 \pm 2.0 \mathrm{mg} \mathrm{g}^{-1}\right)$ more than five times greater than stems $\left(7.0 \pm 0.2 \mathrm{mg} \mathrm{g}^{-1} ; p<0.0001\right)$ and this effect was independent of time or species. Sugar concentrations were $17 \%$ higher in October than March for roots, but remained similar through time in stems (time $\times$ organ interaction; $p<0.0138$; Figure 2). 


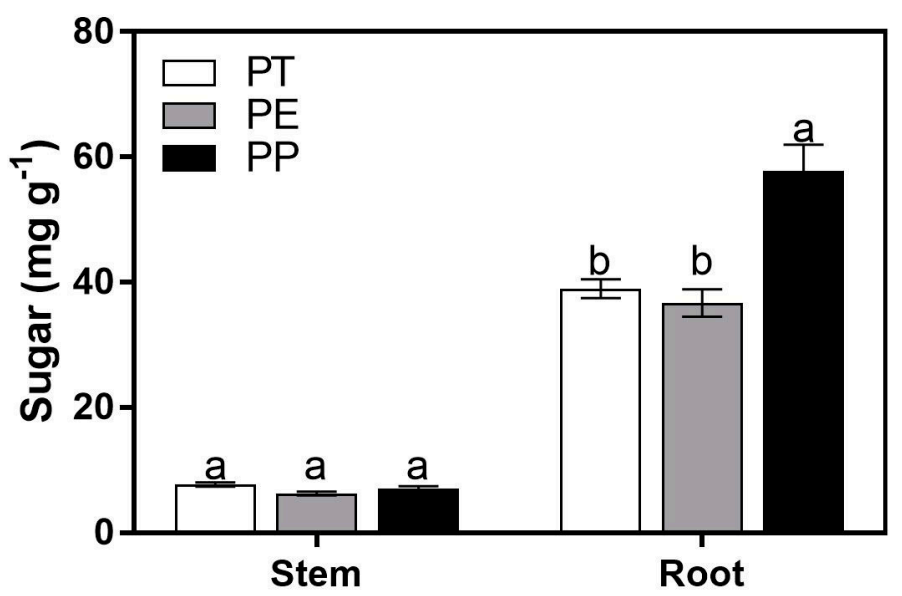

Figure 1. Mean ( \pm standard error $(\mathrm{SE}))$ sugar concentrations $\left(\mathrm{mg} \mathrm{g}^{-1}\right)$ for species $(\mathrm{PT}=$ Pinus tadea, $\mathrm{PE}=$ Pinus elliottii, and PP = Pinus palustris) by organ (stem and root) averaged across months (October and March). Bars with different letters within an organ indicate significant difference $(\alpha=0.05)$.

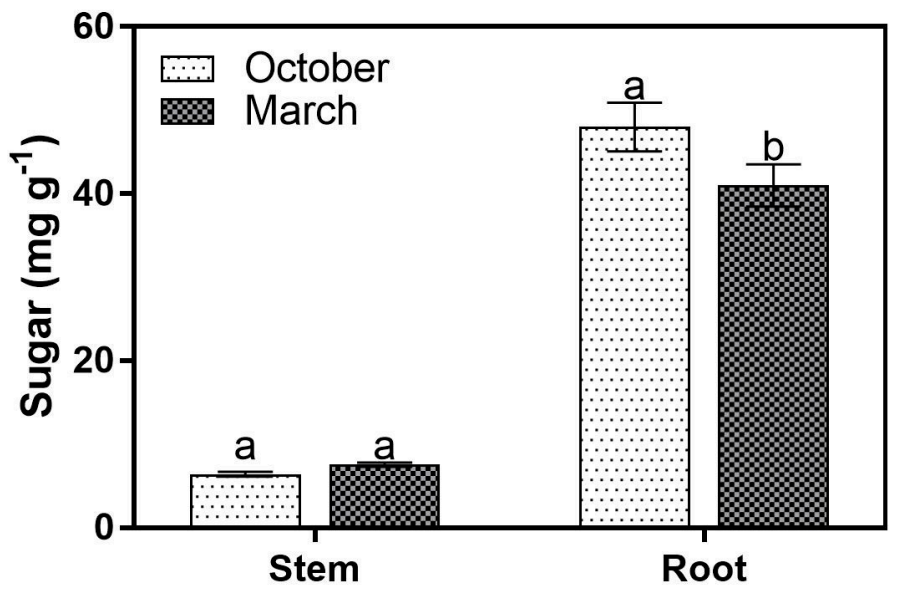

Figure 2. Mean ( $\pm \mathrm{SE}$ ) sugar concentrations $\left(\mathrm{mg} \mathrm{g}^{-1}\right)$ for organ (stem and root) by month (October and March) averaged across species (PT = Pinus tadea, $\mathrm{PE}=$ Pinus elliottii, and $\mathrm{PP}=$ Pinus palustris $)$. Bars with different letters within an organ indicate significant difference $(\alpha=0.05)$.

\subsection{Starch Concentrations}

Starch concentration differed among species, between organs, and changed over time; however, these individual effects were not independent (i.e., species $\times$ organ $\times$ time interaction; $p<0.0305$ ). Longleaf roots exhibited the highest starch concentrations in March when loblolly and slash were similar; however, loblolly roots exhibited higher concentrations than slash in October, whereas longleaf was similar to both (Figure 3). Stems of all species exhibited similar starch concentrations, which remained similar over time (Figure 3). Regardless of the differences among species, root starch concentrations were higher in March than October (Figure 3). Regardless of species, root starch concentrations were higher than stem starch concentrations in March; however, stem and root concentrations were similar in October for longleaf and loblolly, whereas the stem concentrations in slash were higher than the root starch concentration (Figure 3). 


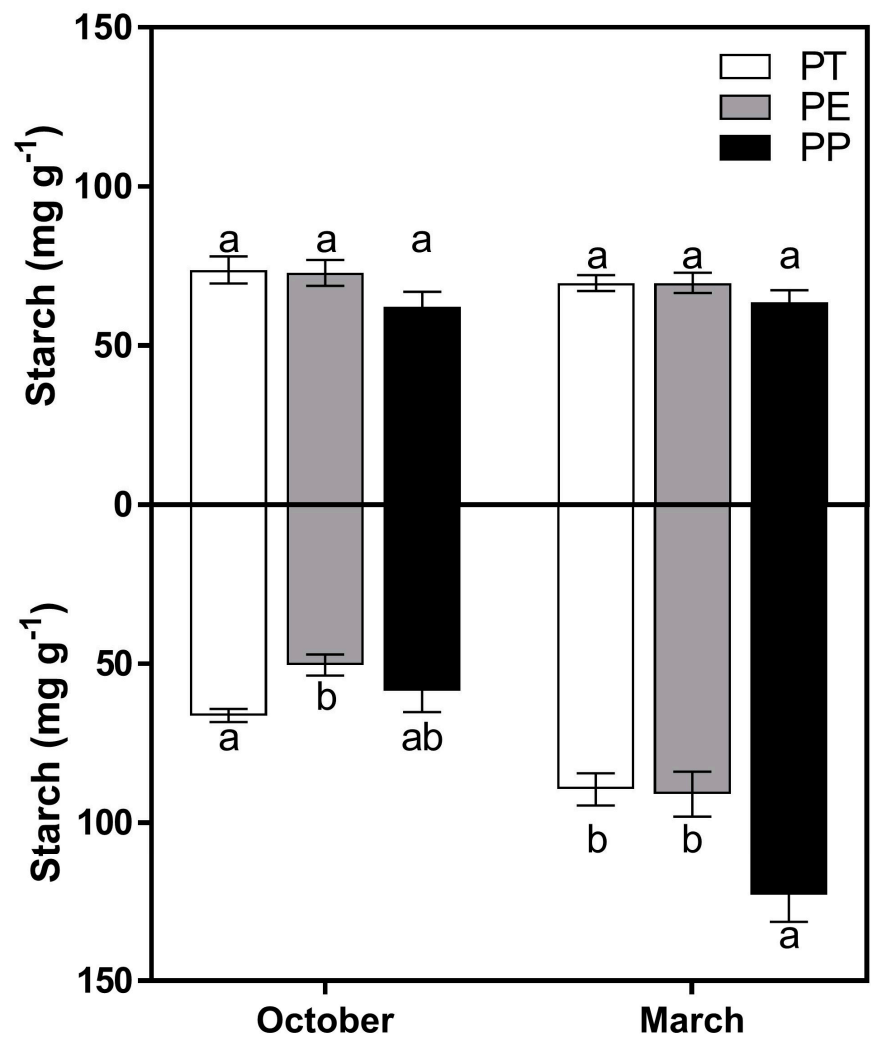

Figure 3. Mean $( \pm \mathrm{SE})$ starch concentrations $\left(\mathrm{mg} \mathrm{g}^{-1}\right)$ for species $(\mathrm{PT}=$ Pinus tadea, $\mathrm{PE}=$ Pinus elliottii, and $\mathrm{PP}=$ Pinus palustris) by month (October and March) by organ (stem and root). Bars with different letters within an organ indicate significant difference $(\alpha=0.05)$.

\subsection{TNC Concentrations}

Starch was the major NSC component for each organ, especially in the stems. Averaging across species and month, starch accounted for $63.2 \%$ and $90.5 \%$ of TNC in roots and stems, respectively. As such, TNC concentrations followed those of starch and differed among species, between organs, and changed over time; however, their individual effects were not always independent. Longleaf roots exhibited higher TNC concentrations than loblolly and slash, which exhibited similar concentrations (Figure 4); however, concentrations in stems were similar among all species (species $\times$ organ interaction; $p<0.0001)$. Roots exhibited $64 \%$ higher TNC concentrations $\left(124.0 \pm 4.4 \mathrm{mg} \mathrm{g}^{-1}\right)$ than stems $\left(75.7 \pm 1.6 \mathrm{mg} \mathrm{g}^{-1} ; p<0.0001\right)$ and this effect was independent of time or species. Roots exhibited $33 \%$ higher TNC concentrations in March than October, but concentrations remained similar over time in stems (time $\times$ organ interaction; $p<0.0001$; Figure 5). 


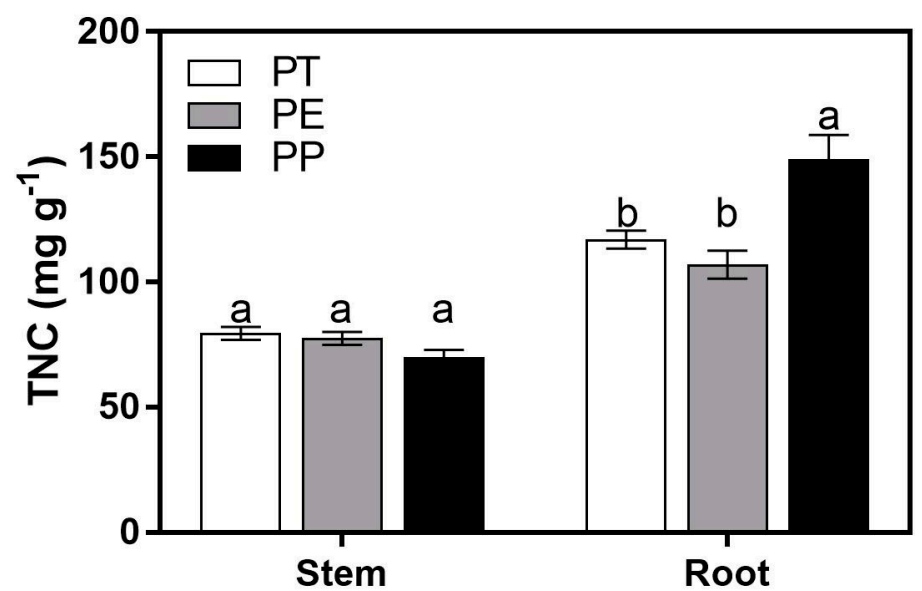

Figure 4. Mean $( \pm \mathrm{SE}) \mathrm{TNC}$ concentrations $\left(\mathrm{mg} \mathrm{g}^{-1}\right)$ for species $(\mathrm{PT}=$ Pinus tadea, $\mathrm{PE}=$ Pinus elliottii, and PP $=$ Pinus palustris) by organ (stem and root) averaged across months (October and March). Bars with different letters within an organ indicate significant difference $(\alpha=0.05)$.

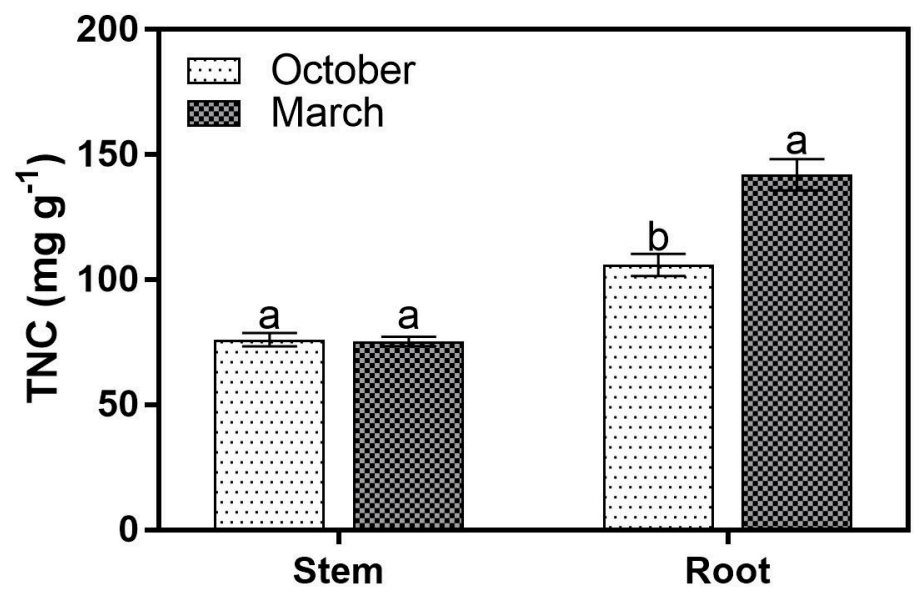

Figure 5. Mean $( \pm \mathrm{SE}) \mathrm{TNC}$ concentrations $\left(\mathrm{mg} \mathrm{g}^{-1}\right)$ for organ (stem and root) by month (October and March) averaged across species (PT = Pinus tadea, $\mathrm{PE}=$ Pinus elliottii, and $\mathrm{PP}=$ Pinus palustris $)$. Bars with different letters within an organ indicate significant difference $(\alpha=0.05)$.

\section{Discussion}

Our results suggest that selective pressures have operated on carbohydrate reserves of southern pine species predominantly at the seedling life-history stage. Longleaf exhibited higher peak starch concentrations in roots than slash or loblolly, which exhibited similar peak starch concentrations. This pattern in root starch concentration among southern pine species reflects their differences in seedling strategy where longleaf relies on sufficient belowground stored carbohydrate reserves to facilitate bolting from the seedling to sapling stage and thereby raise apical meristems to a height that is safe from low-intensity fires [18,22] and/or to refoliate after scorching [1,19]. Starch concentrations in mature stems did not differ among southern pine species, indicating that purported differences in selective pressures have not operated on carbohydrate storage in stems at mature life-history stages, or that any influence at the seedling life-history stage was not maintained through development. Indeed, based on the strategy exhibited by longleaf, we would not expect a benefit of aboveground carbohydrate reserves at the seedling stage because the aboveground storage pool capacity is very small until after bolting occurs. While our findings do not provide definitive proof that selective pressures have operated on carbohydrate reserves at the seedling life-history stage for all three species, the data support that hypothesis and fail to support our alternative hypothesis that selective pressures have operated at the mature life-history stage, which would have resulted in a continuum of starch concentrations based on their relative degree of fire resistance $[23,24]$. On one end of the southern 
pine continuum, longleaf is considered the most fire-tolerant species while loblolly is regarded as the least fire-tolerant with slash considered intermediate [23,24]. However, these three pine species share similar fire-adapted traits that contribute to their fire resistance as mature trees. For example, all three species exhibit self-pruning which impedes fire from climbing branches to the crown $[17,18,25-28]$. All three species also exhibit thick tree bark that insulates the cambium from extreme temperatures associated with fire [17,18,25-30]. The major difference in fire-adapted traits among these three species occurs at the seedling stage.

Fire appears to be the greatest bottleneck for southern pine seedlings to survive and reproduce and there are two general strategies for seedlings to persist and become saplings. The growth strategy exhibited by slash and loblolly seedlings requires longer return intervals of fire disturbances to assure that their seedlings are tall enough to survive fire [17]. However, the rapid stem growth of longleaf seedlings as they transition from the grass stage allows this species to thrive in ecosystems with shorter return intervals of fire $[18,26,30]$. Rather than an indicator of fire adaptation, the two life-history strategies reflect the influence of canopy disturbance, fuel distribution, and fire, a concept known as the "ecology of fuels" [18,31]. Canopy disturbances in longleaf often occur as single tree or small group mortality insufficient to interrupt fuel continuity so seedlings must be able to survive repetitive frequent fire [31]. Slash, loblolly and other similar species such as Caribbean pine (Pinus caribaea Mor.) require an interruption in fuels created by larger gaps for recruitment since their seedlings are prone to fire damage [18]. Increased carbohydrate storage in longleaf pine, which presumably fuels rapid stem growth [22] and refoliates scorched needles [1], provides an advantage that increases the fitness of longleaf seedlings allowing them to survive frequent fire regimes to become sexually mature adults [18,25,26,30,32]. Thus, there would have been a selective advantage for increased belowground carbon storage during the evolutionary history of longleaf which is a function of the interaction of fire with canopy disturbance. Under this framework, the higher starch concentrations observed in mature longleaf could simply be a relic of the selective pressure imposed at the seedling stage.

Disturbance is a strong selective pressure in the evolution of life histories [33,34] and the strength exerted by any particular disturbance increases with its frequency, predictability, and severity [34,35]. Accordingly, we assess the relative selection strength of fire and insect disturbances to understand their relative importance in selecting for carbohydrate reserves. In addition, the evolutionary history of insect attacks could potentially explain the differences in carbohydrate reserves observed among the southern pine species. Carbohydrate reserves play an important role in the production of resin and other secondary compounds that help defend against beetle attack [11]. Also, carbohydrate reserves may help activate defensive mechanisms that are induced by a beetle attack [11,36-39]. Beetles feed on the phloem, cambium, and outer sapwood which can lead to stem girdling [14,40]. Fungal pathogens associated with beetles can also contribute to tree mortality through mycelial penetration of tissues, the release of toxins, or interactions with tree defenses [41]. Successful defense from insects and associated pathogens depends on the quality and quantity of these defensive compounds [12,13,15,38,40]. Trees with greater carbohydrate reserves may be better suited to survive an attack by beetles because there is more substrate available to synthesize defense compounds [13,39]. This suggests there may be a selective advantage for species with greater carbohydrate reserves to better defend against insect attacks. Alternatively, phloem that is rich in carbohydrates is more nutritious and may be preferred by wood-boring insects [42]. Regardless of whether phloem carbohydrate status makes pine trees more preferable or resistant to attack, longleaf seedlings in the grass stage have very little phloem aboveground, which makes them less desirable to wood-boring insects as opposed to mature trees with larger volumes of phloem [38,40,43]. Therefore, we would not expect there to be any selective pressure for carbon storage on juvenile pines imposed by insects. Indeed, beetles are much more likely to attack mature trees than seedlings or saplings. Likewise, despite the potential severity of insect infestations, (see [44,45]), disturbance from insects probably does not exert as strong of a selective force on carbohydrate reserves for mature trees as does fire. Fire is relatively predictable due to flammable fuel loads and abundant ignition opportunities [46]. The thin, long 
needles of pines result in fuel loads with low compaction which help attribute to the low severity of fire [28]. The highly flammable needles provide abundant opportunities for frequent fire which keeps fire intensity low $[28,32]$. Damage from fire, if it occurs at all, may not be as severe as damage from insects, but its predictability and high frequency make fire the most likely selective driver for the carbohydrate reserves observed in longleaf either at juvenile or mature life-history stages.

Although we acknowledge there are numerous factors throughout the life history of long-lived organism that exert selective pressures, it appears the selective pressures that resulted in the seedling strategy exhibited by longleaf pine have provided additional benefits at the mature life-history stage. For example, longleaf can rapidly replace scorched needles using belowground carbohydrate reserves [1] and can maintain the normal metabolic demands of longleaf roots for more than a year without any additional carbohydrate supply [3]. Although we lack similar controlled experiments with slash and loblolly, anecdotal observation suggests they are also capable of refoliating; however, our results indicate that longleaf would have larger reserves and should have a greater capacity to repair damaged tissues and maintain existing tissues. For example, loblolly is not capable of maintaining normal metabolic demands of roots with belowground carbohydrate reserves for even much shorter periods [47]. While slash and loblolly appear to rely on belowground carbohydrate reserves to some extent, longleaf appears to depend on belowground starch reserves much more for metabolism as they deplete these reserves during the growing season and replenish reserves during the dormant season [3]. In our study, longleaf depleted three times as much starch (64 $\left.\mathrm{mg} \mathrm{g}^{-1}\right)$ as loblolly (23 $\left.\mathrm{mg} \mathrm{g}^{-1}\right)$, which depleted about half of what slash depleted $\left(41 \mathrm{mg} \mathrm{g}^{-1}\right)$. Seasonal patterns of root carbohydrate accretion and depletion have been reported in longleaf [3] and many other species [48]. It is important to note that our inference is based on a presumed similarity in seasonal patterns of carbohydrate accretion and depletion among our threes species as well as similarities in belowground mass (i.e., storage reservoir $=$ mass $\times$ concentration). While we cannot be completely certain of these similarities, they are reasonable assumptions considering their phenological similarities and past reports of similar belowground biomass among these species from a single site [49]. Apparently, similar temporal dynamics of accretion and depletion of stored carbohydrates does not occur in the stems of these southern pine species. This conforms to results from another study where 10 temperate forest species did not exhibit significant seasonal differences in the NSC concentrations of stems [50]. Likewise, Pinus slyvestris L. did not exhibit seasonal differences in NSC concentrations of stems [51]. However, NSC concentrations in stems of Larix gmelinii Rupr. and Fraxinus mandshurica Rupr. exhibited seasonal dynamics similar to those observed in roots [52]. When seasonal dynamics in stems are not observed it does not, however, necessarily indicate that carbohydrate reserves are not used. Indeed, it is possible that these reserves are maintained within a narrow threshold and rapidly replenished quickly following use, either from recent assimilation or perhaps from storage reserves in roots.

Large carbohydrate reserves in roots are common in species that experience aboveground disturbances [53]. Perhaps resprouters are the best example of increased root storage of NSC for post-disturbance recovery [54,55]. Resprouters like Stirlingia latifolia R. Br. allocate most of its NSC reserves in the roots to aid in recovery from severe fire disturbances [56]. One reason for this increased storage of carbohydrate reserves to belowground organs is that NSC is better protected belowground from aboveground disturbances [53,57]. Here we have shown that mature longleaf, while not a resprouter, stores carbohydrates in the root system at higher concentrations than observed in other southern pine species. Although this is likely an artifact of selective pressures at the seedling life-history stage that facilitate bolting, refoliating, and ultimately, recruitment to the canopy, the carry-over effect confers a benefit to mature trees that enhance their overall resilience. Although slash and loblolly exhibited similar maximum starch concentrations in roots, slash depleted these reserves more than loblolly, but not as much as longleaf. Such differences in the dependence on carbohydrate reserves suggests that, in addition to the evolutionary history of fire, some other selective pressure has influenced carbohydrate reserves in these species. 


\section{Conclusions}

Our results indicated that there was not a pattern of stored carbohydrate concentrations among the pines that would be a predicted adaptation to a continuum of fire frequency across the evolutionary history of these three species. Rather, our results showed that longleaf exhibited higher root carbohydrate reserves than slash and loblolly (which did not differ) suggesting that developmental inertia from adaptations that conferred higher fitness at the seeding stage carry into maturity. This reflects the importance of how interacting disturbances must also be considered in explaining patterns of traits in an evolutionary context. In this case, seedling life history can be predicted by the interaction between fire and the scale of canopy disturbances that either maintain or interrupt fuel continuity. The relative resistance to other disturbances such as insect attack also appears decoupled from fire since slash and longleaf beetle resistance is related to the kind of chemical defense, not the quantity of carbohydrates available to draw on during attack. That carbohydrate storage among these closely-related pines at mature life history stages was best explained by their seedling strategies suggests that similar patterns may be observed in other species. For example, resprouters may maintain high carbohydrate reserves as mature trees, even when they reach sizes or ages where they are no longer able to repsrout, but these reserves may still provide other benefits. Indeed, additional research efforts aimed at exploring these ideas more rigorously across southern pines (e.g., by sampling seasonally along a developmental sequence that includes seedlings, saplings, and mature trees) or across different species with respect to similar or different functional traits will help provide context to our findings.

Author Contributions: D.P.A. and J.T.M. conceptualized and designed the project. J.T.M. collected and analyzed data. J.T.M. and D.P.A. prepared the manuscript. D.P.A. and J.J.O. revised the manuscript.

Funding: This material is based upon work supported by the Department of Energy under Award Number DE-EM0004391 to the University of Georgia Research Foundation.

Conflicts of Interest: The authors declare no conflict of interest.

\section{References}

1. Aubrey, D.P.; Mortazavi, B.; O’Brien, J.J.; McGee, J.D.; Hendricks, J.J.; Kuehn, K.A.; Teskey, R.O.; Mitchell, R.J. Influence of repeated canopy scorching on soil $\mathrm{CO}_{2}$ efflux. For. Ecol. Manag. 2012, 282, 142-148. [CrossRef]

2. Guo, D.L.; Mitchell, R.J.; Hendricks, J.J. Fine root branch orders respond differentially to carbon source-sink manipulations in a longleaf pine forest. Oecologia 2004, 140, 450-457. [CrossRef] [PubMed]

3. Aubrey, D.P.; Teskey, R.O. Stored root carbohydrates can maintain root respiration for extended periods. New Phytol. 2018, 218, 142-152. [CrossRef] [PubMed]

4. Minelli, A. A principle of developmental inertia. In Epigenetics: Linking Genotype and Phenotype in Development and Evolution; University of California Press: Oakland, CA, USA, 2011; pp. 116-133.

5. Minelli, A. Animal development, an open-ended segment of life. Biol. Theory 2011, 6, 4-15. [CrossRef]

6. Farjon, A. A Natural History of Conifers; Timber Press: Portland, OR, USA, 2008.

7. Stanturf, J.A.; Wade, D.D.; Waldrop, T.A.; Kennard, D.K.; Achtemeier, G.L. Fire in southern forest landscapes. In Southern Forest Resource Assessment; Gen. Tech. Rep. SRS-53; Wear, D.M., Greis, J., Eds.; US Dept. Agric., Forest Service, Southern Research Station: Asheville, NC, USA, 2002; Chapter 25; pp. 607-630.

8. Platt, W.J.; Glitzenstein, J.S.; Streng, D.R. Evaluating Pyrogenicity and Its Effects on Vegetation in Longleaf Pine Savannas. In Proceedings of the Tall Timbers Fire Ecology Conference, Tallahassee, FL, USA, 30 May2 June 1991; pp. 143-161.

9. Landers, J.L.; Wade, D. Disturbance Influences on Pine Traits in the Southeastern United States. In Proceedings of the Tall Timbers Fire Ecology Conference, Tallahassee, FL, USA, 30 May-2 June 1991; Tall Timbers Research Station: Tallahassee, FL, USA, 1991; pp. 61-98.

10. Hare, R.C. Contribution of bark to fire resistance of southern trees. J. For. 1965, 63, 248-251.

11. Guérard, N.; Maillard, P.; Bréchet, C.; Lieutier, F.; Dreyer, E. Do trees use reserve or newly assimilated carbon for their defense reactions? A ${ }^{13} \mathrm{C}$ labeling approach with young scots pines inoculated with a bark-beetle-associated fungus (Ophiostoma brunneo ciliatum). Ann. For. Sci. 2007, 64, 601-608. [CrossRef] 
12. Keeling, C.I.; Bohlmann, J. Genes, enzymes and chemicals of terpenoid diversity in the constitutive and induced defence of conifers against insects and pathogens. New Phytol. 2006, 170, 657-675. [CrossRef] [PubMed]

13. Warren, J.M.; Allen, H.L.; Booker, F.L. Mineral nutrition, resin flow and phloem phytochemistry in loblolly pine. Tree Physiol. 1999, 19, 655-663. [CrossRef] [PubMed]

14. Friedenberg, N.A.; Whited, B.M.; Slone, D.H.; Martinson, S.J.; Ayres, M.P. Differential impacts of the southern pine beetle, Dendroctonus frontalis, on Pinus palustris and Pinus taeda. Can. J. For. Res. 2007, 37, 1427-1437. [CrossRef]

15. Hodges, J.D.; Elam, W.W.; Watson, W.F.; Nebeker, T.E. Oleoresin characteristics and susceptibility of four southern pines to southern pine beetle (coleoptera: Scolytidae) attacks. Can. Entomol. 1979, 111, 889-896. [CrossRef]

16. Keeley, J.E.; Zedler, P.H. Evolution of life histories in pinus. In Ecology and Biogeography of Pinus; Cambridge University Press: Cambridge, UK, 2000; p. 219.

17. Outcalt, K.W. The longleaf pine ecosystem of the south. Nat. Plants J. 2000, 1, 42-53. [CrossRef]

18. O'Brien, J.J.; Hiers, J.K.; Callaham, M.A., Jr.; Mitchell, R.J.; Jack, S.B. Interactions among overstory structure, seedling life-history traits, and fire in frequently burned neotropical pine forests. AMBIO: J. Hum. Environ. 2008, 37, 542-547. [CrossRef]

19. Pile, L.S.; Wang, G.G.; Knapp, B.O.; Liu, G.; Yu, D. Comparing morphology and physiology of southeastern us pinus seedlings: Implications for adaptation to surface fire regimes. Ann. For. Sci. 2017, 74, 68. [CrossRef]

20. Dietze, M.C.; Sala, A.; Carbone, M.S.; Czimczik, C.I.; Mantooth, J.A.; Richardson, A.D.; Vargas, R. Nonstructural carbon in woody plants. Annu. Rev. Plant Biol. 2014, 65, 667-687. [CrossRef] [PubMed]

21. Buysse, J.; Merckx, R. An improved colorimetric method to quantify sugar content of plant tissue. J. Exp. Bot. 1993, 44, 1627-1629. [CrossRef]

22. Wahlenberg, W.G. Longleaf Pine: Its Use, Ecology, Regeneration, Protection, Growth, and Management; C.L. Pack Forestry Foundation and USDA Forest Service: Washington, DC, USA, 1946.

23. De Ronde, C. The resistance of Pinus species to fire damage. S. Afr. For. J. 1982, 122, $22-27$.

24. McCune, B. Ecological diversity in North American pines. Am. J. Bot. 1988, 75, 353-368. [CrossRef]

25. He, T.; Pausas, J.G.; Belcher, C.M.; Schwilk, D.W.; Lamont, B.B. Fire-adapted traits of pinus arose in the fiery cretaceous. New Phytol. 2012, 194, 751-759. [CrossRef] [PubMed]

26. Keeley, J.E. Ecology and evolution of pine life histories. Ann. For. Sci. 2012, 69, 445-453. [CrossRef]

27. Keeley, J.E.; Pausas, J.G.; Rundel, P.W.; Bond, W.J.; Bradstock, R.A. Fire as an evolutionary pressure shaping plant traits. Trends Plant Sci. 2011, 16, 406-411. [CrossRef] [PubMed]

28. Pausas, J.G. Evolutionary fire ecology: Lessons learned from pines. Trends Plant Sci. 2015, 20, 318-324. [CrossRef] [PubMed]

29. Pausas, J.G.; Keeley, J.E. A burning story: The role of fire in the history of life. Bioscience 2009, 59, 593-601. [CrossRef]

30. Van Lear, D.; Harlow, R. Fire in the eastern United States: Influence on wildlife habitat. In Proceedings: Role of Fire for Nongame Wildlife Management and Community Restoration: Traditional Uses and New Directions; Gen. Tech. Rep. NE-288; Ford, W.M., Russell, K.R., Moorman, C.E., Eds.; US Dept. of Agriculture, Forest Service, Northeastern Research Station: Newtown Square, PA, USA, 2002.

31. Mitchell, R.J.; Hiers, J.K.; O’Brien, J.; Starr, G. Ecological forestry in the southeast: Understanding the ecology of fuels. J. For. 2009, 107, 391-397.

32. Fonda, R.W. Burning characteristics of needles from eight pine species. For. Sci. 2001, 47, 390-396.

33. Sousa, W.P. The role of disturbance in natural communities. Annu. Rev. Ecol. Syst. 1984, 15, 353-391. [CrossRef]

34. White, P.S. Pattern, process, and natural disturbance in vegetation. Bot. Rev. 1979, 45, 229-299. [CrossRef]

35. Lytle, D.A. Disturbance regimes and life-history evolution. Am. Nat. 2001, 157, 525-536. [PubMed]

36. Lahr, E.C.; Sala, A. Species, elevation, and diameter affect whitebark pine and lodgepole pine stored resources in the sapwood and phloem: Implications for bark beetle outbreaks. Can. J. For. Res. 2014, 44, 1312-1319. [CrossRef]

37. Lombardero, M.; Ayres, M.P.; Lorio, P.L., Jr.; Ruel, J.J. Environmental effects on constitutive and inducible resin defences of Pinus taeda. Ecol. Lett. 2000, 3, 329-339. [CrossRef] 
38. Christiansen, E.; Waring, R.H.; Berryman, A.A. Resistance of conifers to bark beetle attack: Searching for general relationships. For. Ecol. Manag. 1987, 22, 89-106. [CrossRef]

39. Christiansen, E.; Ericsson, A. Starch reserves in Picea abies in relation to defence reaction against a bark beetle transmitted blue-stain fungus, Ceratocystis polonica. Can. J. For. Res. 1986, 16, 78-83. [CrossRef]

40. Berryman, A.A. Resistance of conifers to invasion by bark beetle-fungus associations. Bioscience 1972, 22, 598-602. [CrossRef]

41. Paine, T.; Raffa, K.; Harrington, T. Interactions among scolytid bark beetles, their associated fungi, and live host conifers. Annu. Rev. Entomol. 1997, 42, 179-206. [CrossRef] [PubMed]

42. Raffa, K.F.; Phillips, T.W.; Salom, S.M. Strategies and mechanisms of host colonization by bark beetles. In Beetle-Pathogen Interactions in Conifer Forests; Academic Press: London, UK, 1993; pp. 102-128.

43. Berryman, A.A. Theoretical explanation of mountain pine beetle dynamics in lodgepole pine forests. Environ. Entomol. 1976, 5, 1225-1233. [CrossRef]

44. Billings, R. Southern pine beetle: Impact in wilderness and non-wilderness forests. Tex. For. 1994, 35, 16-17.

45. Raffa, K.F.; Aukema, B.H.; Bentz, B.J.; Carroll, A.L.; Hicke, J.A.; Turner, M.G.; Romme, W.H. Cross-scale drivers of natural disturbances prone to anthropogenic amplification: The dynamics of bark beetle eruptions. AIBS Bull. 2008, 58, 501-517. [CrossRef]

46. Outcalt, K.W. Lightning, fire and longleaf pine: Using natural disturbance to guide management. For. Ecol. Manag. 2008, 255, 3351-3359. [CrossRef]

47. Johnsen, K.; Maier, C.; Sanchez, F.; Anderson, P.; Butnor, J.; Waring, R.; Linder, S. Physiological girdling of pine trees via phloem chilling: Proof of concept. Plant Cell Environ. 2007, 30, 128-134. [CrossRef] [PubMed]

48. Martinez-Vilalta, J.; Sala, A.; Asensio, D.; Galiano, L.; Hoch, G.; Palacio, S.; Piper, F.I.; Lloret, F. Dynamics of non-structural carbohydrates in terrestrial plants: A global synthesis. Ecol. Monogr. 2016, 86, 495-516. [CrossRef]

49. Gibson, M.D.; McMillin, C.W.; Shoulders, E. Above- and Below-Ground Biomass of Four Species of Southern Pine Growing on Three Sites in Louisiana; USDA Forest Service Final Report FS-SO-3201-59; USDA, Forest Service, Southern Forest Experiment Station: Pineville, LA, USA, 1985.

50. Hoch, G.; Richter, A.; Korner, C. Non-structural carbon compounds in temperate forest trees. Plant Cell Environ. 2003, 26, 1067-1081. [CrossRef]

51. Terziev, N.; Boutelje, J.; Larsson, K. Seasonal fluctuations of low-molecular-weight sugars, starch and nitrogen in sapwood of pinus sylvestris L. Scand. J. For. Res. 1997, 12, 216-224. [CrossRef]

52. Mei, L.; Xiong, Y.; Gu, J.; Wang, Z.; Guo, D. Whole-tree dynamics of non-structural carbohydrate and nitrogen pools across different seasons and in response to girdling in two temperate trees. Oecologia 2015, 177, 333-344. [CrossRef] [PubMed]

53. Iwasa, Y.; Kubo, T. Optimal size of storage for recovery after unpredictable disturbances. Evol. Ecol. 1997, 11, 41-65. [CrossRef]

54. Schutz, A.E.N.; Bond, W.J.; Cramer, M.D. Juggling carbon: Allocation patterns of a dominant tree in a fire-prone savanna. Oecologia 2009, 160, 235-246. [CrossRef] [PubMed]

55. Clarke, P.J.; Knox, K.J.E. Trade-offs in resource allocation that favour resprouting affect the competitive ability of woody seedlings in grassy communities. J. Ecol. 2009, 97, 1374-1382. [CrossRef]

56. Bowen, B.J.; Pate, J.S. The significance of root starch in post-fire shoot recovery of the resprouter Stirlingia latifolia r. Br. (proteaceae). Ann. Bot. 1993, 72, 7-16. [CrossRef]

57. Clarke, P.J.; Lawes, M.J.; Midgley, J.J.; Lamont, B.B.; Ojeda, F.; Burrows, G.E.; Enright, N.J.; Knox, K.J.E. Resprouting as a key functional trait: How buds, protection and resources drive persistence after fire. New Phytol. 2013, 197, 19-35. [CrossRef] [PubMed]

(C) 2018 by the authors. Licensee MDPI, Basel, Switzerland. This article is an open access article distributed under the terms and conditions of the Creative Commons Attribution (CC BY) license (http:/ / creativecommons.org/licenses/by/4.0/). 